Edunomika - Vol. 03, No. 02 (Agustus 2019)

\title{
ANALISIS KEPUASAN PELANGGAN ATAS KUALITAS PELAYANAN PADA PT AUTOMOBIL JAYA MANDIRI WULING DI SURAKARTA,
}

\author{
ENDAH ASTUTI \\ Jurusan Manajemen Universitas Islam Batik Surakarta \\ Email : endah.astuti@gmail.com
}

\begin{abstract}
Abstrak: Tujuan dari penelitian ini adalah untuk mengetahui pengaruh kualitas pelayanan terhadap kepuasan pelanggan Dealer PT. Automobil Jaya Mandiri Wuling Surakarta secara parsial dan simultan.Sumber data primer diperoleh dari kuesioner yang dibagikan pada konsumen dengan jumlah sampel 95 orang, sedangkan data sekunder diperoleh dari PT. Automboil Jaya Mandiri Wuling Surakarta. Alat analisis yang digunakan adalah dengan analisis deskriptif kuantitatif. Berdasar hasil uji t dapat disimpulkan bahwa bahwa ada pengaruh secara parsial antara variabel tangible dan assurance terhadap kepuasan pelanggan pada Dealer PT. Automoil Jaya Mandiri Wuling Surakarta. Hasil uji $F$ menunjukkan bahwa terdapat pengaruh secara simultan antara variabel tangible, reliability, responsible, assurance, empathy terhadap kepuasan konsumen pada Dealer PT. Automobil Jaya Mandiri Wuling Surakarta. Hasil uji regresi linier berganda diperoleh persamaan $Y=1,219+0,763 X 1-0,064 X 2+0,130 X 3+0,748 X 4-8,644 X 5 €$. Dari persamaan regresi tersebut dapat diketahui bahwa varibel yang paling dominan berpengaruh terhadap kepuasan konsumen adalah variabel bukti fisik dengan koefisien 0,763. Uji $R 2$ (R Square) didapatkan hasil sebesar 0,609 atau 60,9\% yang berarti bahwa kepuasan konsumen pada Dealer PT. Automobil Jaya Mandiri Wuling Surakarta dipengaruhi oleh variabel tangiable, reliabelity, responsible, assurance, empathy sebesar 60,9\%. Dan faktor lain yang mempengaruhi kepuasan konsumen pada Dealer PT. Automobil Jaya Mandiri Wuling Surakarta. sebesar 0,391 (39,1\%) diharapkan Dealer PT. Automobil Jaya Mandiri Wuling Surakarta perlu menerapkan dan mengembangkan aspek pelayanan terhadap kepuasan konsumen yang mencakup tangible (bukti fisik), reliability (kehandalan), responsiveness (daya tanggap), assurance (jaminan), empathy (empati), sehingga dapat memperoleh pangsa pasar yang lebih baik.
\end{abstract}

Kata kunci : Kualitas Pelayanan dan Kepuasan Pelanggan

\begin{abstract}
The purpose of this study was to determine the effect of service quality on customer satisfaction PT. Automobil Jaya Mandiri Wuling Surakarta partially and simultaneously. Primary data sources were obtained from questionnaires distributed to consumers with a sample of 95 people, while secondary data were obtained from PT. Automboil Jaya Mandiri Wuling Surakarta. The analytical tool used is quantitative descriptive analysis. Based on the results of the $t$ test, it can be concluded that there is a partial effect between tangible and assurance on customer satisfaction at PT. Automobil Jaya Mandiri Wuling Surakarta. F test results show that there is a simultaneous influence between tangible, reliable, responsible, assurance, empathyvvariables on customer satisfaction at PT. Automobil Jaya Mandiri Wuling Surakarta. The
\end{abstract}


results of multiple linear regression tests obtained by the equation $Y=1,219+0.763 X 1$ $0.064 X 2+0.130 X 3+0.748 X 4-8.644 X 5 €$. From the regression equation it can be seen that the most dominant variable influencing consumer satisfaction is the physical evidence variable with a coefficient of 0.763. R2 (R Square) test obtained a result of 0.609 or $60.9 \%$ which means that customer satisfaction with the Dealer of PT. Automobil Jaya Mandiri Wuling Surakarta is influenced by variable tangiable, reliable, responsible, assurance, empathy of $60.9 \%$. And other factors that influence customer satisfaction at PT. Automobil Jaya Mandiri Wuling Surakarta. of 0.391 (39.1\%) expected by PT. Automobil Jaya Mandiri Wuling Surakarta needs to implement and develop aspects of service to consumer satisfaction which include tangible (physical evidence), reliability (reliability), responsiveness (responsiveness), assurance (empathy), empathy (empathy), so as to obtain a more market share well.

Keywords: Service Quality, Tangible, Reliability, Responsiveness, Assurance, Empathy, and Customer Satisfaction

\section{PENDAHULUAN}

Semakin banyak perusahaan yang berkembang, maka persainganpun akan menjadi lebih ketat. Kondisi seperti ini sangat berpengaruh terhadap laba perusahaan, dengan begitu hal yang harus diperhatikan dan diprioritaskan adalah memuaskan konsumen, supaya konsumen dapat bertahan dan perusahaan dapat bersaing dengan pesaing yang lain serta dapat menguasai pangsa pasar.

Dalam memenuhi kepuasan pelanggan dengan memberikan pelayanan yang baik maka PT. Automobil Jaya Mandiri Wuling perlu mengetahui perilaku pelanggan yang sangat beragam.

Dari kondisi tersebut perlu adanya penelitian kualitas pelayanan servis mobil pada dealer Wuling Solo, sehingga dapat diidentifikasi adakah pengaruh kepuaan pelanggan atas kualitas dan dimensi kualitas pelayanan manakah yang paling dominan dalam memberikan pengaruh terhadap tingkat kepuasan pelanggan dalam melakukan servis motor pada dealer Automobil Jaya Mandiri Wuling sebagai upaya peningkatan kualitas pelayanan servis motor pada dealer Automobil Jaya Mandiri Wuling.

Berdasarkan latar belakang diatas, maka penulis ingin melakukan penelitian dengan perumusan asalah sebagai berikut: 1. Apakah bukti fisik, keandalan, daya tanggap, jaminan, dan empati berpengaruh simultan terhadap kepuasan pelanggan pada PT. Automobil Jaya Mandiri Wuling Surakarta?, 2.Apakah bukti fisik berpengaruh terhadap kepuasan pelanggan pada PT. Automobil Jaya Mandiri Wuling Surakarta?, 3.Apakah keandalan berpengaruh terhadap kepuasan pelanggan PT. Automobil Jaya Mandiri Wuling Surakarta?, 4.Apakah daya tanggap berpengaruh terhadap kepuasan pelanggan pada PT. Automobil Jaya Mandiri Wuling Surakarta?, 5.Apakah jaminan berpengaruh terhadap kepuasan pelanggan pada PT. Automobil Jaya Mandiri Wuling Surakarta ?, 6.Apakah empati berpengaruh terhadap kepuasan pelanggan pada PT. Automobil Jaya Mandiri Wuling Surakarta?.

\section{TINJAUAN PUSTAKA}

Pengertian Kepuasan Konsumen

Kepuasan pelanggan merupakan hal yang penting dalam sebuah perusahaan. Hasil 
penilaian pelanggan terhadap sesuatu yang diharapkan dengan membeli dan mengkonsumsi suatu produk. Harapan tersebut dibandingkan dengan persepsinya terhadap kinerja yang diterima pelanggan dengan mengkonsumsi produk tersebut (Aritonang, 2010).

\section{Pengertian Kualitas Pelayanan}

Kualitas pelayanan merupakan ukuran seberapa baik tingkat layanan yang diberikan sesuai harapan pelanggan. Dua faktor utama yang mempengaruhi kualitas pelayanan yaitu expected service dan perceived service. Apabila jasa yang diterima, atau dirasakan (perceived service) sesuai dengan yang diharapkan maka kualitas pelayanan dipersepsikan baik atau memuaskan, begitu sebaliknya (Parasuraman 1985).

Terdapat lima dimensi kualitas pelayanan menurut Parasuraman seperti dikutip oleh Lupiyoadi (2006:182), yaitu:

a) Tangible, adalah kemampuan perusahaan menunjukkan keberadaannya pada pihak eksternal melalui sarana dan prasarana fisik, dan keadaan lingkungan sekitarnya sebagai bukti nyata dan pelayanan yang diberikan.

b) Reliability, merupakan kemampuan perusahaan untuk memberikan pelayanan sesuai dengan yang dijanjikan dengan akurat dan terpercaya.

c) Responsiveness, yaitu kesediaan perusahaan untuk memberikan pelayanan yang cepat dan tepat kepada pelanggan dengan cara penyampaian informasi yang jelas.

d) Assurance, yaitu pengetahuan dan kemampuan dari para pegawai perusahaan dalam menumbuhkan rasa percaya pelanggan kepada perusahaan.

e) Empathy, merupakan kemampuan perusahaan dalam memahami keinginan pelanggan dan menghargai pelanggan

\section{Dimensi Kualitas Pelayanan}

Bukti fisik merupakan penampilan organisasi yang menjadi sangat penting dalam membentuk kesan awal atau dalam menciptakan harapan pelanggan. peran pengepakan ini khususnya penting dalam menciptakan harapan dari konsumen baru dan untuk perusahaan jasa yang baru berdiri yang sedang mencoba membangun suatu image (Zeithaml, et al. dalam Tjiptono: 2006).

Keandalan adalah kemungkinan produk untuk tidak berfungsi pada periode waktu tertentu, yang intinya reliabilitas (kepercayaan) adalah saat seluruh Informan percaya bahwa pelayanan kesehatan di tempat kesehatan tertentu bagi mereka sangat memuaskan dan seperti yang diharapkan. (Zahruli, 2006)

Daya tanggap yaitu sikap tanggap pegawai dalam memberikan pelayanan yang dibutuhkan dan dapat menyelesaikan dengan cepat. Kecepatan pelayanan yang diberikan merupakan sikap tanggap dari petugas dalam pemberian pelayanan yang dibutuhkan. Sikap tanggap ini merupakan suatu akibat akal dan pikiran yang ditunjukkan pada pelanggan. (Parasuraman et al (dalam Zeithaml dan Bitner (1996: 118).

Assurance atau jaminan merupakan pengetahuan dan perilaku employee untuk membangun kepercayaan dan keyakinan pada diri para pengguna jasa yang ditawarkan. (Parasuraman dalam Zeithaml, dan L.L. Berry, 1998). 
Menurut Zeithaml et al., (1985). Empati (empathy) adalah adanya kemudahan dalam melakukan hubungan komunikasi yang baik dan pemahaman atas kebutuhan para pelanggannya. Aspek empati dalam menjalankan perusahaan jasa menjadi hal yang sangat penting, karena antara produksi dan penyajiannya terhadap pelanggan berjalan secara langsung.

\section{METODE PENELITIAN}

Jenis penelitian ini merupakan penelitian deskriptif kuantitatif, populasi penelitian ini yaitu adalah semua customer yang pernah berlangganan servis, tehnik pengamilan ample menggunakan tehnik purposive sampling, penelitian ini mengambil sample sebesar 95 responden. Metode analisis yang digunakan adalah metode analisis regresi linear, metode pengumpulan data dengan menyearkan lembar kuesioner.

\section{ANALISIS DATA DAN PEMBAHASAN}

Analisis Data

\section{a. Uji Asumsi Klasik}

Berdasarkan hasil pengujian menunjukan nilai dari perhitungan SPSS 21 asymp.sig sebesar 0,697 hal ini menunjukan bahwa data dalam penelitian ini normal.

b. Uji Multikolinearitas

menurut Priyatno (2011:195) uji multikolinearitas adalah alat untuk menguji korelasi antar variabel independen berikut ini hasil uji multikolinearitas pada tabel berikut:

\section{Hasil Uji Multikolinieritas}

\begin{tabular}{|c|c|c|c|c|c|}
\hline Keterangan & Tolerance & Std & VIF & Std & Kesimpulan \\
\hline Bukti Fisik & 0,104 & $>0,10$ & 9,652 & $<10$ & $\begin{array}{l}\text { Tidak ada } \\
\text { Multikolinearitas }\end{array}$ \\
\hline Keandalan & 0,451 & $>0,10$ & 2,215 & $<10$ & $\begin{array}{l}\text { Tidak ada } \\
\text { Multikolinearitas }\end{array}$ \\
\hline $\begin{array}{l}\text { Daya } \\
\text { Tanggap }\end{array}$ & 0,434 & $>0,10$ & 2,302 & $<10$ & $\begin{array}{l}\text { Tidak ada } \\
\text { Multikolinearitas }\end{array}$ \\
\hline Jaminan & 0,648 & $>0,10$ & 1,543 & $<10$ & $\begin{array}{l}\text { Tidak ada } \\
\text { Multikolinearitas }\end{array}$ \\
\hline Empati & 0,105 & $>0,10$ & 9,532 & $<10$ & $\begin{array}{l}\text { Tidak ada } \\
\text { Multikolinearitas }\end{array}$ \\
\hline
\end{tabular}

Dari tabel diatas dari semua variabel nilai tolerance $>10$ dan nilai $\mathrm{VIF}<10$ maka dapat disimpulkaan bahwa seluruh variabel tidak terjadi multikolinearitass. 
c. Uj Heterokedastisitas

Uji Heterokedastisitas bertujuan menguji apakah dalam model regresi terjadi ketidaksamaan varian dari residual satu pengamatan ke pengamatan yang lain. apabila terdapat pola seperti bergelombang, melebar dan menyempit maka terjadi heteroskedastisitas namun jika tidak terdapat pola dan titik yang menyebar dibawah dan diatas angka nol (0) pada sumbu Y maka tidak terjadi heteroskedastisitas. (Maryam, 2015: 62-63).

Hasil Uji Heterokedastisitas

\begin{tabular}{llcc}
\hline Variabel & Sig & Batas & Kesimpulan \\
\hline Bukti Fisik & 0,080 & $>0,05$ & Tidak terjadi Heterokedastisistas \\
Keandalan & 0,227 & $>0,05$ & Tidak terjadi Heterokedastisistas \\
Daya & 0,934 & $>0,05$ & Tidak terjadi Heterokedastisistas \\
Tanggap & & & \\
Jaminan & 0,215 & $>0,05$ & Tidak terjadi Heterokedastisistas \\
Empati & 0,056 & $>0,05$ & Tidak terjadi Heterokedastisistas \\
\hline
\end{tabular}

Berdasarkan data tabel diatas dapat diketahui bahwa probabilitas value $\mathrm{X} 1, \mathrm{X}_{2}, \mathrm{X} 3, \mathrm{X} 4$ dan $\mathrm{X}$, lebih besar (>) 0,05 yang berarti tidak terjadi heterokedastisitas.

\section{Analisis Data dan Hipotesis}

Analisis Regresi Linear Berganda Berikut ini tabel uji regresi linear berganda :

\section{Hasil Uji Regresi Linear Berganda}

\begin{tabular}{lcccc}
\hline Variabel & $\mathrm{B}$ & $\mathrm{t}$ hitung & Sig t & Keterangan \\
\hline Constant & 1,219 & 0,517 & 0,606 & \\
Bukti Fisik & 0,763 & 3,650 & 0,000 & Signifikan \\
Kehandalan & $-0,064$ & $-0,555$ & 0,580 & Tidak Signifikan \\
Daya Tanggap & 0,130 & 0,129 & 0,316 & Tidak Signifikan \\
Jaminan & 0,748 & 8,208 & 0,000 & Signifikan \\
Empati & $-8,644$ & $-3,227$ & 0,002 & Tidak Signifikan \\
maka dapat disusun & analisis & & Dari persamaan regresi tersebut \\
\hline \multicolumn{2}{r}{ regresi sebagai berikut : }
\end{tabular}




$$
\begin{aligned}
& \mathrm{Y}=1,219+0,763 \mathrm{X} 1+-0,064 \mathrm{X} 2+ \\
& 0,130 \mathrm{X} 3+0,748 \mathrm{X} 4+-8,644 \mathrm{X} 5
\end{aligned}
$$

dapat diinterpretasikan sebagai berikut:

a) Nilai konstanta sebesar 1,219 menunjukan bahwa jika semua variabel independen nilainya 1 , maka kepuasan pelanggan akan meningkat sebesar 1,219.

b) Nilai koefisien b1 sebesar 0,763 berarti kualitas pelayanan bukti fisik berpengaruh positif terhadap kepuasan pelanggan. Jika kualitas pelayanan bukti fisik meningkat maka kepuasan pelanggan akn meningakat sebesar 0,763 .

c) Nilai koefisien b2 sebesar -0,064 berarti apabila kehandalan mengalami tingkatan sebesar satu satuan, maka kepuasan pelanggan dapat menurun sebesar -0,064. Karena nilai koefsien regresi bernilai minus maka dengan demikian dapat dikatakan bahwa kehandalan berpengaruh negaif terhadap kepuasan pelanggan.

d) Nilai koefisien b3 sebesar 0,130 berarti daya tanggap berpengaruh positif terhadap kepuasan pelanggan. Jika kualitas pelayanan bukti fisik meningkat maka kepuasan pelanggan sebesar 0,130 .

e) Nilai koefisien b4 sebesar 0,748 berarti jaminan berpengaruh positif terhadap kepuasan pelanggan. Jika jaminan meningkat maka kepuasan pelanggan akan meningkat sebesar 0,748.

f) Nilai koefisien b5 sebesar $-8,644$ berarti apabila empati mengalami tingkatan sebesar satu satuan, maka kepuasan pelanggan dapat menurun sebesar $-8,644$. Karena nilai koefsien regresi bernilai minus maka dengan demikian dapat dikatakan bahwa empati berpengaruh negaif terhadap kepuasan pelanggan.

2. Uji F

Uji $\mathrm{F}$ digunakan untuk mengetahui pengaruh variabel independen atau variabel bebas yaitu bukti fisik $\left(\mathrm{X}_{1}\right)$, kehandalan $\left(\mathrm{X}_{2}\right)$, daya tanggap $\left(\mathrm{X}_{3}\right)$, jaminan $\left(\mathrm{X}_{4}\right)$, dan empati $\left(\mathrm{X}_{5}\right)$ secara simultan terhadap variabel terikat atau variabel dependen yaitu kepuasan pelanggan (Y). Berikut hasil analisis dengan menggunakan program SPSS versi

21 dalam sajian tabel :

\begin{tabular}{|c|c|c|c|c|c|}
\hline Model & Fhitung & Ftabel & $\mathrm{Sig}$ & Std & Keterangan \\
\hline 1 & 27,697 & 2,32 & 0,000 & & Model Layak \\
\hline
\end{tabular}

\section{Hasil Analisis Uji F}


3. Uji t

Uji t, menguji seerapa kuat pengaruh variael bebas pada sebuah penelitian mampu menerangkan variael terikat secara individual (Ghozali 2012:

98), dari perhitungan yang dilakukan diketahui bahwa:

a) Nilai Fhitung > Ftabel $(27,697>2,32)$ maka Ho ditolak, sehingga variabel bukti fisik, kehandalan, daya tanggap, jaminan, dan empati berpengaruh secara simultan terhadap kepuasan pelanggan dealer Wuling Surakarta.

b) Hasil perhitungan $\mathrm{t}$ statistic untuk variabel bukti fisik (X1) diperoleh nilai thitung sebesar 3,650 sedangkan besar $t$ tabel adalah 1,987 (thitung<ttabel). Sehingga dapat disimpulkan bahwa ada pengaruh signifikan bukti fisik (X1) terhadap kepuasan pelanggan.

c) Hasil perhitungan $\mathrm{t}$ statistik untuk variabel keandalan (X2) diperoleh nilai thitung sebesar -0,555 sedangkan besar ttabel adalah 1,987 (thitung<ttabel) sehingga dapat disimpulkan bahwa Ho diterima berarti kehandalan tidak berpengaruh signifikan terhadap kepuasan pelanggan.

d) Hasil perhitungan $\mathrm{t}$ statistik untuk variabel daya tanggap (X3) diperoleh nilai thitung sebesar 1,007 sedangkan besar ttabel adalah 1,987 (thitung>ttabel) dengan nilai sinigfikan sebesar 0,316 > 0,05 sehingga dapat disimpulkan bahwa Ho diterima berarti daya tanggap tidak berpengaruh signifikan terhadap kepuasan pelanggan.

e) Hasil perhitungan t statistik untuk variabel jaminan (X4) diperoleh nilai thitung sebesar 8,208 sedangkan besar ttabel adalah 1,987 (thitung>ttabel) sehingga dapat disimpulkan bahwa Ho ditolak berarti terdapat pengaruh signifikan jaminan (X4) terhadap kepuasan pelanggan.

f) Hasil perhitungan t statistik untuk variabel empati (X5) diperoleh nilai thitung sebesar -3,227 sedangkan besar ttabel adalah 1,987 (thitung>ttabel) sehingga dapat disimpulkan bahwa Ho diterima berarti kehandalan tidak berpengaruh signifikan terhadap kepuasan pelanggan.

4. Uji Koefisien Determinasi $\left(\mathrm{R}^{2}\right)$

$\mathrm{R}^{2}$ ( $\mathrm{R}$ square) merupakan alat ukur yang bertujuan untuk mengetahui keterlibatan seberapa jauh variabel independen dan variabel dependen. Hasil perhitungan $\mathrm{R}^{2}$ diperoleh sebesar 0,609. Hal ini berarti bahwa variabel bukti fisik $\left(\mathrm{X}_{1}\right)$, kehandalan $\left(\mathrm{X}_{2}\right)$, daya tanggap $\left(\mathrm{X}_{3}\right)$, jaminan (X4), dan empati (X5) memberikan sumbangan variabel independen terhadap variabel dependen. Sumbangan variabel independen sebesar $0,609 \quad(60,9 \%)$ sedangkan $0,391(39,1 \%)$ dipengaruhi oleh variabel-variabel lain.

\section{KESIMPULAN}

a) Bukti fisik berpengaruh positif dan signifikan terhadap kepuasan pelanggan PT.Automobil Jaya Mandiri Wuling.

b) Kehandalan berpengaruh negatif tidak signifikan terhadap kepuasan pelanggan PT.Automobil Jaya Mandiri Wuling.

c) Daya tanggap berpengaruh positif tidak signifikan terhadap kepuasan pelanggan PT.Automobil Jaya Mandiri Wuling.

d) Jaminan berpengaruh positif dan signifikan terhadap kepuasan pelanggan PT.Automobil 
Jaya Mandiri Wuling.

e) Empati berpengaruh negatif tidak signifikan terhadap kepuasan pelanggan PT. Automobil Jaya Mandiri Wuling.

\section{Saran}

a) Sebaiknya perusahaan memberikan pelatihan pelayanan yang lebih baik kepada karyawan. Lebih tepatnya kehandalan, daya tanggap dan empati dimana faktor- faktor tersebut masih sangat kurang.

b) Dari sisi bukti fisik dan jaminan terus ditingkatkan. Misalnya seperti perbaikan ruang tunggu bisa ditambahkan fasilitas lain yang membuat pelanggan nyaman untuk menunggu, dan penguatan jaminan yang lebih seperti perbanyak promosi dengan mengunggulkan jaminan yang ada di dealer Wuling.

\section{DAFTAR PUSTAKA}

Kausar Musa. 2016. Service Quality And Customer Satisfaction Among Domestic Air Passengers In Nigeria. International Journal Of Business And Management Studies Vol. 8. No. 2.

Afrinda Edy, dan Kholid. 2015. Pengaruh Kualitas Pelayanan Terhadap Kepuasan Pelanggan Fedex Express Surabaya Jurnal Manajemen Ilmu Surakarta. Vol. 13. No. 1.

Marjan Sadeghdaghighi1 and Mehrdad Goudarzvand Chegini. 2016. Analysis of Services Quality on Customer's Satisfaction Using SERVQUAL Model . Journal of Engineering Technology American Society Enginering Education. Vol. 5. Issue 1.

Istiatin dan Eswika. 2016. Pengaruh Kualitas Pelayanan Terhadap Kepuasan Konsumen Pada Dealer PT.Ramayana Motor Sukoharjo. Jurnal Ekonomi Manajemen Universitas Islam Batik Administrasi Bisnis Universitas Brawijaya Malang. Vol. 25 No. 2

Efendi Januar dan Yuliati. 2016. Pengaruh Kualitas Pelayanan Terhadap Kepuasan Pelanggan Pada Jne Cabang Bandung. Prodi Administrasi Bisnis, Jurnal Manajemen Fakultas Komunikasi Dan Bisnis Universitas Telkom. Vol. 11 No. 2

Sugiyono.2016.Metode Penelitian Kuantitatif, Kualitatif, dan $\quad$ R\&D. Bandung :Alfabeta Suprianto, D.; Susanta, H. and Nurseto, S. (2014). The effect of product design, price and location toward purchase decision. Jurnal Ilmu Administrasi Bisnis. Vol. 3 No. 4.

Tjiptono, Fandy. 2015.Strategi Pemasaran.Edisi 4. Yogyakarta: ANDI.

Priyatno, Dwi. 2011. Buku Saku SPSS. Analasis Statistik Dengan Microsoff Excel \& SPSS. Penerbit Andi. Yogyakarta. 
Rochyan, Warso dan Aziz. 2016. Pengaruh Kualitas Pelayanan Terhadap Kepuasan Konsumen Studi Kasus Pada Konsumen Pt. Graha Service Indonesia Cabang Semarang. Jurnal Manajemen. Universias Negeri Semarang Vol.4 No.1 Maret 2016

Sari Atul Hilaliyah, Achmad Helmy Djawahir, Christin Susilowati. 2017. Pengaruh Kualitas Layanan Dan Kualitas Produk Yang Di Moderasi Oleh Suasana Terhadap Kepuasan Pelanggan Jurnal Mananajemen Fakultas Ekonomi Dan Bisnis Universitas Brawijaya. Vol. 4 No.2. 